\title{
Taxonomic Composition and Population Level of the Prosthetic Bed Mucosa Microbiota in Case of Dentition Defects in Patients Wearing Partial Dentures
}

\author{
Zinoviy Ozhogan ${ }^{1}$, Mykola Yasinskyi2*, Olexander Belikov², Roman Levandovskyi ${ }^{2}$
}

\begin{abstract}
The article considers the taxonomic composition and the population level of the oral cavity microbiota and changes in their characteristics after prosthetic rehabilitation with partial removable dentures. In the patients with partial loss of teeth wearing conventional removable dentures, the taxonomic composition of the gingiva microbiota changes due to the biotope contamination with opportunistic $S$. aureus and yeast-like fungi of the Candida genus, S. haemolyticus, K. pneumoniae, enterobacteria (E.coli, K.pneumoniae, E.cloacae), B.catarralis, M.lacunata and partial elimination of $S$. sialivarius, S.sanguis, S. mutans, S. mitis from the biota.

The objective of the research was to study changes in the gingiva in the examined patients.

Materials and Methods. Microbiological (bacteriological and mycotic) examination of gum mucus secretion in the patients with partial loss of teeth was performed. The control group consisted of 50 (23 men and 27 women) patients without any infectious and noncommunicable diseases, who had no problems adapting to removable denture during the last 6 months.

Results and Discussion. In $78.72 \%$ of the patients, microorganisms isolated and identified from the surface of the prosthetic bed, were in associations that consisted of $2(31.70 \%), 3(8.51 \%)$ and $4(8.51 \%)$ taxons. The most numerous associations consisting of 2 taxons were: $S$. aureus and $M$. lacunata; $S$. aureus and $N$. flavescens; $S$. haemolyticus and B.catarrhalis as well as $C$. albicans and $S$. epidermidis. In the biotope (the surface of the gum mucosa of the prosthetic bed) of the patients wearing partial removable laminar dentures, the population level reduced in S. salivarius, S. sanguis, S. mutans, S. mitis and significantly increased in opportunistic staphylococci (S. aureus, S. haemolyties, S. epidermidis), S. pyogenes, enterobacteria (E. coli, K. pneumoniae, E. clocacae), B.catarrhalis. Microorganisms $S$. aureus and $C$. albicans reached a high population level; it increased in $S$. haemoliticus, S. epidermidis, S. pyogenes, E. coli, E. cloacae, K. pneumoniae as well.

Conclusions. In the patients with partial loss of teeth wearing conventional removable dentures, the taxonomic composition of the gingiva microbiota changed due to the contamination of the habitat with opportunistic $S$. aureus and yeast-like fungi of the Candida genus, S. haemolyticus, K. pneumoniae, enterobacteria (E.coli, K. pneumoniae, E. cloacae), B. catarralis, M. lacunata and partial elimination of S. sialivarius, S.sanguis, S. mutans, S. mitis from the biota.
\end{abstract}

\section{Keywords}

partial removable dentures; taxonomic composition; population level

${ }^{1}$ Ivano-Frankivsk National Medical University, Ivano-Frankivsk, Ukraine

${ }^{2}$ Bukovinian State Medical University, Chernivtsi, Ukraine

*Corresponding author: khvilovyyyy@gmail.com 


\section{Problem statement and analysis of the latest research}

Dental defect restoration plays a significant role in orthopaedic dentistry. Among the main causes of tooth loss, there are dental caries and its complications, inflammatory and dystrophic-inflammatory diseases of the periodontal tissues, traumas. Solving this problem by mounting partial removable dentures has clear indications, namely loss of teeth in case of free-end and bounded edentulous space, and combined dentition defects. However, prosthetic repair with these structures has many disadvantages including the change in the oral cavity microflora and the decrease in the reactivity of the tissues of the prosthetic bed mucous membrane at the point of contact with both the elements of removable prosthesis and the entire oral cavity $[9,5,6,7]$.

The isolation and identification of microorganism associations from the prosthetic bed tissues, comparing these indices to the oral cavity microflora of apparently healthy individuals are an important diagnostic method for treating and preventing clinical manifestations of adaptation disorders in the patients with partial removable prostheses $[2,8]$.

It is also important to determine dynamic changes in the oral mucosa microbiota in the patients with dentition defects before and after prosthetic repair.

The objective of the research was to identify the tachonomic composition, population level and microecological parameters of the prosthetic bed mucous membrane microbiota in the patients with partial removable dentures.

\section{Materials and Methods}

Microbiological (bacteriological and mycotic) examination of gum mucus secretion in the patients with partial loss of teeth was performed.

The control group consisted of 50 (23 men and 27 women) patients without any infectious and noncommunicable diseases, who had no problems adapting to removable denture during the last 6 months.

In the patients and apparently healthy individuals (the control group), oral fluid and mucosal secretion of the prosthetic bed were sampled with sterile cotton swabs. After sampling the material, the sterile cotton swab was squeezed against the wall of a sterile centrifuge tube (not less than $0.5 \mathrm{ml}$ ). A ten-fold volume of buffer solution was added to the material, and the material was diluted at 1:10 $\left(10^{-1}\right)$. A titration mixture was prepared from the main material diluted serially $10^{-1}$ to $10^{-7}$. In each dilution, $0.01 \mathrm{ml}$ of the mixture was collected and plated on the sectors with the best medium for each taxon, grinding the material with sterile glass spatulas. All inoculations were incubated in a thermostat at the temperature of $37^{\circ} \mathrm{C}$, and $-23^{\circ} \mathrm{C}$ for yeast-like fungi.

Staphylococci and enterococci were tested on egg-yolk salt agar; streptococci were tested on nutrient media containing blood or serum. The isolation and identification of Candida species were carried out on a sabouraud medium [1,9].

Enterobacteria were grown and identified on differential diagnostic media (Endo, Levin, Ploskirev). The total number of aerobic microorganisms and their hemolytic properties were determined by plating the material on 5\% meat infusion agar.

An ecological method was used to reveal the mechanisms of contamination and colonization of biota by microorganisms, which allowed us to determine the features of co-existing the representatives of the "microorganism - microbiota" ecological system and the ability to dynamic changes in the gum mucosal microbiota in the patients with partial tooth loss. Dominance typology was carried out based on the constancy index determined. To characterize the microbiocenosis diversity of the gum mucosa, the Margalef species richness index and the Whittaker species diversity index were calculated $[3,7,10]$.

To determine the dominance degree for a certain microorganism species in the gum mucosa of the patients with partial tooth loss, the species-domination Simpson index and Berger-Parker index were calculated.

The results obtained were processed using the MYSTAT 2 (USA) software. The reliability of the data for independent samples was calculated by means of the Student's t-criterion (with an array distribution close to normal). The difference was considered reliable at $\mathrm{p}<0.05$. 


\section{Results and Discussion}

The results of studying the taxonomic composition of the gum mucosal microbiota in the patients with partial loss of teeth are presented in Table 1.

In apparently healthy individuals, the main microbiota of the gum mucosa was represented by Streptococus salivarius.

Additional microbiota was represented by $S$. sanguis. Other microorganisms, presented by the constancy index, the incidence frequency, the Margalef species richness index, the Whittaker species diversity index, the Simpson and Berger-Parker species domination index were detected as occasional ones (Table 1).

In the patients with partial loss of teeth, among the listed ecological indices, S.aureus was often found being the leading causative agent of the inflammatory process. S.epidermis, S.hemolyticus, S.pyogenus, E. coli, Acinetobacter spp., B. sattaralis, $N$. flavescens, M.lacunata and C. albicans were rare.

In 47 patients, 26 strains of microorganisms belonging to 16 different taxonomic groups were isolated and identified, which, according to the Margaleff species richness index and the Whittaker species diversity index, testifies to the fact that in the biotope, after partial loss of teeth, spatial, nutritional and other conditions are created for the development of microbiota in associative groups. Table 2 shows the results of determining the quantitative characteristics for the association of opportunistic microorganisms on the surface of the prosthetic bed mucosa in the patients with partial tooth loss.

In the gum mucosa of most patients (78.72\%) with partial loss of teeth, microorganism associations consisting of 2,3 , and 4 microorganism species belonging to different taxonomic groups persisted. Therefore, the inflammatory processes in the gum mucosa of the patients with partial loss of teeth, were caused by associations of opportunistic microorganisms having a variety of species interrelations. The results of determining qualitative characteristics and opportunistic microorganism associations on the surface of the gum mucosa in the patients with partial loss of teeth are presented in
Table 3.

Only in $10(8.51 \%)$ patients with partial loss of teeth, monoculture was detected on the gum mucosa; more frequently, it was the monoculture of $S$. pyogenes. In most patients, associations consisting of 2 taxons were revealed. Associations of $S$. aureus and $N$. lacunata, S. hemolyticus and B. Catarralis, $S$. epidermidis and $C$. albicans were detected in five $(10.64 \%)$ patients. Other associations, consisting of 2, 3 and 4 taxons, were observed less frequently.

The best spatial and nutrient conditions for the existence, growth and reproduction of microbial association are known to be created in each taxon in the biotope. Individual microorganisms of this biotope grow, reproduce and reach a high population level, becoming the leading agents (factors) of the pathological process in the biotope. To establish this characteristic in the associations, we studied the population level of each taxon forming an association on the gum mucosa in the patients with partial tooth loss (Table 4).

The highest population level in the gum mucosal secretion of the patients with partial secondary tooth loss was found in S. pyogenes; a slightly lower level was observed in staphylococci, colibacilli, acinetobacteria, branhamella, and others.

In the patients with partial tooth loss, the population level of $S$. pyogenes on the mucosa increased by 2.2 times, B. catarrhalis - by $97.67 \%$, Actinobacter - by $94.94 \%, S$. hemolyticus - by $61.11 \%$, E. Coli - by $59.70 \%$, E. cloacae - by $59.33 \%$, S. epidermidis - by $49.35 \%, K$. pneumoniae - by $43.0 \%, N$. flavescens - by $25.60 \%$, M. lacunata - by $20.46 \%$. Microorganisms contaminating the surface of the prosthetic bed mucosa - S. aureus and C. albicans - reached the high population level, $S$. salivarius increased by $61.13 \%, S$. mitris - by $33.58 \%, S$. mutans - by $18.10 \%$, S. sanguis - by $14.67 \%$.

When comparing these indicators with those obtained by other researchers [9, 10], in the first case, our data differed by $21-65 \%$, while in the second case, they differed by $7-19 \%$ only. 
Table 1. Microbiota taxons of the oral cavity in the examined patients.

\begin{tabular}{|c|c|c|c|c|c|c|c|c|c|c|c|c|c|c|c|}
\hline \multirow{3}{*}{ Microbiota taxons } & \multicolumn{7}{|c|}{ Patients with partial secondary adentia $(n=47)$} & \multicolumn{7}{|c|}{ Apparently healthy individuals $(\mathrm{n}=50)$} & \multirow{3}{*}{$\mathrm{p}$} \\
\hline & \multirow[t]{2}{*}{ 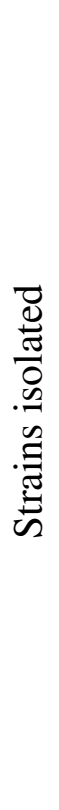 } & \multirow[t]{2}{*}{ 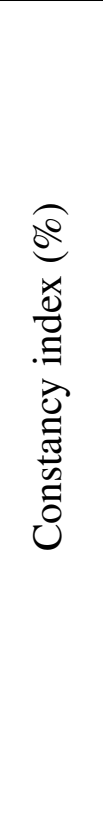 } & \multirow[t]{2}{*}{ 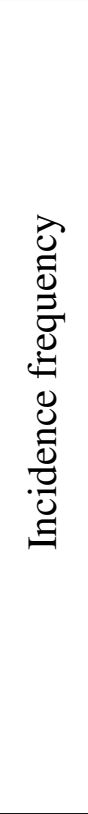 } & \multirow[t]{2}{*}{ 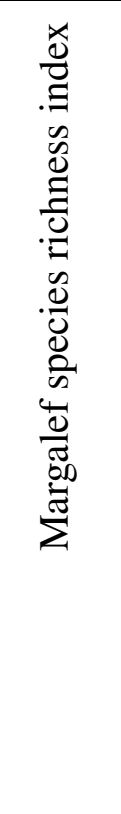 } & \multirow[t]{2}{*}{ 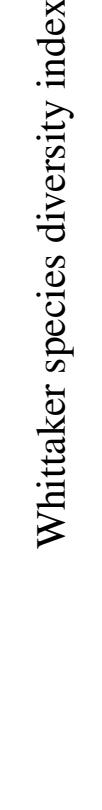 } & \multicolumn{2}{|c|}{ 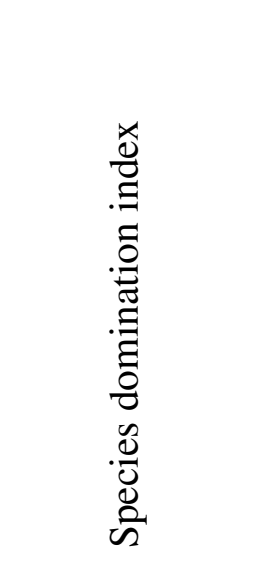 } & \multirow[t]{2}{*}{ 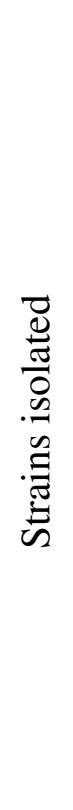 } & \multirow[t]{2}{*}{ 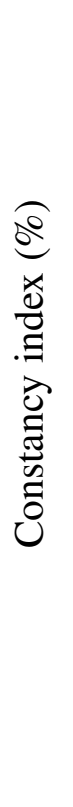 } & \multirow[t]{2}{*}{ 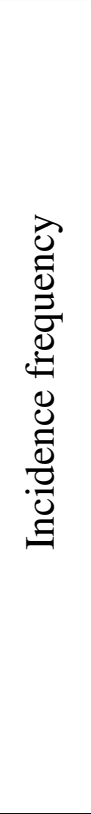 } & \multirow[t]{2}{*}{ 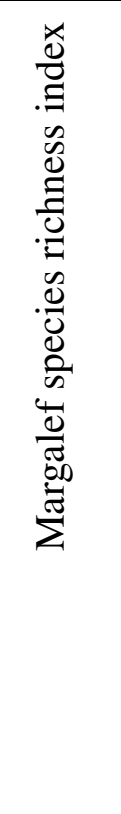 } & \multirow[t]{2}{*}{ 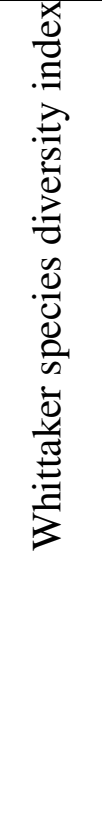 } & \multicolumn{2}{|c|}{ 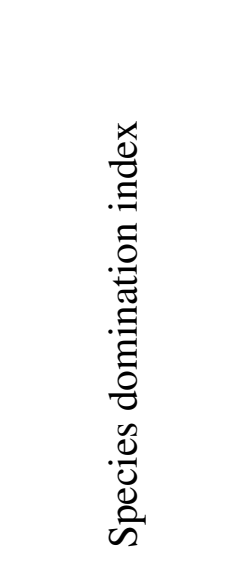 } & \\
\hline & & & & & & 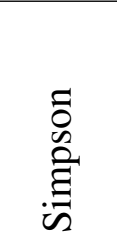 & 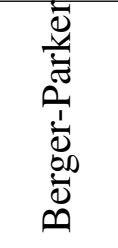 & & & & & & 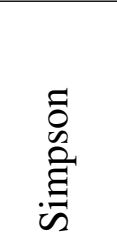 & 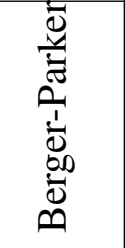 & \\
\hline S. aureus & 18 & 38.3 & 0.18 & 0.173 & 3.55 & 0.184 & 0.032 & - & - & - & - & - & - & - & - \\
\hline S. epidermidis & 6 & 12.77 & 0.06 & 0.051 & 1.18 & 0.061 & 0.003 & 7 & 14 & 0.06 & 0.055 & 1.68 & 0.064 & 0.004 & $>0.05$ \\
\hline S. haemolytics & 8 & 17.02 & 0.08 & 0.071 & 1.58 & 0.082 & 0.006 & 2 & 4 & 0.02 & 0.009 & 0.48 & 0.018 & - & $<0.05$ \\
\hline S. pyogenus & 8 & 17.02 & 0.08 & 0.071 & 1.58 & 0.082 & 0.006 & 5 & 10 & 0.05 & 0.037 & 1.2 & 0.046 & 0.002 & $>0.05$ \\
\hline S. salivarius & 2 & 4.56 & 0.02 & 0.01 & 0.39 & 0.02 & - & 47 & 94 & 0.43 & 0.469 & 11.3 & 0.431 & 0.184 & $<0.01$ \\
\hline S. sanguis & 3 & 6.38 & 0.03 & 0.02 & 0.59 & 0.031 & 0.001 & 12 & 24 & 0.11 & 0.101 & 2.88 & 0.11 & 0.011 & $<0.05$ \\
\hline S. mutans & 2 & 4.56 & 0.02 & 0.01 & 0.39 & 0.02 & - & 8 & 16 & 0.07 & 0.064 & 1.92 & 0.073 & 0.005 & $>0.05$ \\
\hline S. mitry & 2 & 4.56 & 0.02 & 0.01 & 0.39 & 0.02 & - & 7 & 14 & 0.96 & 0.055 & 1.68 & 0.064 & 0.004 & $>0.05$ \\
\hline E. coli & 7 & 14.89 & 0.07 & 0.061 & 1.38 & 0.071 & 0.004 & 2 & 4 & 0.02 & 0.009 & 0.48 & 0.018 & - & $>0.05$ \\
\hline K. pneumoniae & 4 & 8.51 & 0.04 & 0.031 & 0.79 & 0.041 & 0.001 & 1 & 2 & 0.01 & - & 0.24 & 0.009 & - & - \\
\hline E. cloacae & 2 & 4.56 & 0.02 & 0.01 & 0.39 & 0.02 & - & 1 & 2 & 0.01 & - & 0.24 & 0.009 & - & - \\
\hline Acinetobacter & 5 & 10.64 & 0.05 & 0.041 & 0.99 & 0.051 & 0.002 & 5 & 10 & 0.05 & 0.037 & 1.2 & 0.046 & 0.002 & $>0.05$ \\
\hline B. catarrhalis & 9 & 19.15 & 0.09 & 0.082 & 1.78 & 0.092 & 0.008 & 1 & 2 & 0.01 & - & 0.24 & 0.009 & - & - \\
\hline N. pneumoniae & 7 & 14.89 & 0.07 & 0.061 & 1.38 & 0.071 & 0.004 & 6 & 12 & 0.06 & 0.046 & 1.44 & 0.055 & 0.003 & $>0.05$ \\
\hline M. lacunata & 7 & 14.89 & 0.07 & 0.061 & 1.38 & 0.071 & 0.004 & 4 & 8 & 0.04 & 0.028 & 0.96 & 0.037 & 0.001 & $>0.05$ \\
\hline C. albicans & 8 & 17.02 & 0.08 & 0.071 & 1.58 & 0.082 & 0.006 & - & - & - & - & - & - & - & - \\
\hline
\end{tabular}




\section{Taxonomic Composition and Population Level of the Prosthetic Bed Mucosa Microbiota in Case \\ of Dentition Defects in Patients Wearing Partial Dentures - 5/8}

Thus, in the patients with partial loss of teeth, the concentration of autochthonous obligatory and facultative streptococci on the gum mucosa ( $S$. sallivarius, S. sanguis, $S$. mutans, $S$. mytri) reduced, whereas the population level of $S$. pyogenus $S$., epidermidis, S. haemoliticus, enterobacteria (E. coli, K. pneumoniae, E. cloacae), Acinetobacter, B.cattaralis, N.flavescens, N..lacunata and yeast-like fungi of the Candida genus increased.

The study of changes in the taxonomic composition of the oral mucosa microbiota in the patients wearing partial removable dentures is an important diagnostic method that should be used by dentists in their practice when the process of adaptation to new prosthetic construction is complicated. The long-term consequences of poor patients' adaptation to partial dentures may include infectious and inflammatory processes in the oral cavity tissues; as a result, such use becomes impossible, patients' quality of life and trust in their health care professional worsen [3, 4]. The use of rational and timely therapy in significant changes of the taxonomic composition allow preventing the onset of the process and curing the complications developed on their background.

The use of partial removable laminar dentures has many disadvantages; one of them is the change in the oral cavity microflora and the reactivity of the tissues of the prosthetic bed mucous membrane at the point of contact with both the elements of removable prosthesis and the entire oral cavity [7].

The isolation and identification of microorganism associations from the prosthetic bed tissues, the comparison of these indicators with the oral cavity microflora of apparently healthy individuals are an important diagnostic method for treatment and prevention of clinical manifestations of adaptation disorders in the patients with partial removable dentures [8].

The determination of dynamic changes in the oral mucosa microbiota in the patients with dentition defects before and after prosthetic repair is important as well $[9,10]$.

The issues of optimizing the schemes for the prevention of changes in the taxonomic composition of the oral mucosa microbiota when using partial removable dentures, determining of microbial resistance to various groups of drugs, prolonged effect of drugs directly in the oral cavity at different stages of the adaptation to partial removable dentures remain relevant.

\section{Conclusions}

1. In the patients with partial tooth loss wearing conventional removable dentures, the taxonomic composition of the gingiva microbiota changed due to the contamination of the habitat with opportunistic $S$. aureus and yeast-like fungi of the Candida genus, S. haemolyticus, K. pneumoniae, enterobacteria (E.coli, K. pneumoniae, E. cloacae), B. catarralis, $M$. lacunata and partial elimination of $S$. sialivarius, S. sanguis, S. mutans, S. mitis from the biota.

2. In $78.72 \%$ of the patients, microorganisms isolated and identified from the surface of the prosthetic bed, were in associations that consisted of 2 $(31.70 \%), 3(8.51 \%)$ and $4(8.51 \%)$ taxons. The most numerous associations consisting of 2 taxons were: S. aureus and M. lacunata; S. aureus and $N$. flavescens; $S$. haemolyticus and B.catarrhalis as well as $C$. albicans and $S$. epidermidis.

3 . In the biotope (the surface of the gum mucosa of the prosthetic bed) of the patients wearing partial removable laminar dentures, the population level reduced in $S$. salivarius, $S$. sanguis, $S$. mutans, $S$. mitis and significantly increased in opportunistic staphylococci ( $S$. aureus, S. haemolyties, S. epidermidis), S. pyogenes, enterobacteria (E. coli, $K$. pneumoniae, E. clocacae), B.catarrhalis. Microorganisms $S$. aureus and $C$. albicans reached a high population level; it increased in $S$. haemoliticus, $S$. epidermidis, S. pyogenes, E. coli, E. cloacae, K. pneumoniae as well.

\section{Prospects of Further Researches}

The study of the possibilities for stabilizing the taxonomic composition and population level of the prosthetic bed mucous membrane microbiota in the patients wearing partial removable denture, is promising. 
Table 2. Quantitative associations of opportunistic microorganisms in the patients with partial secondary adentia.

\begin{tabular}{l|c|c|c|c|c}
\hline \multirow{2}{*}{ Indices } & $\begin{array}{c}\text { Number of } \\
\text { patients } \\
\text { examined }\end{array}$ & \multicolumn{4}{|l}{ Microorganisms associations, including 13 taxons } \\
\hline Patients examined & 47 & 2 taxons & 3 taxons & 4 taxons & 5 taxons \\
\cline { 2 - 6 } & 100 & 10 & 20 & - & - \\
\hline Percentage of patients & 96 & 10 & 61.7 & 8.51 & 8.5 \\
Isolated and identified taxons & 100 & 10.42 & 60.42 & 12.5 & 16.66 \\
Percentage of taxons & &
\end{tabular}

Table 3. Qualitative characteristics and opportunistic microorganism of the gum mucosa in the patients with partial tooth loss.

\begin{tabular}{|c|c|c|c|}
\hline Taxons & & Abs & $\%$ \\
\hline & Opportunistic microorganism monocultures & & \\
\hline \multirow{4}{*}{ I. } & S. pyogenes & 4 & 8.51 \\
\hline & S. aureus & 3 & 6.38 \\
\hline & E. coli & 2 & 4.26 \\
\hline & B. catarrhalis & 1 & 2.13 \\
\hline \multirow{11}{*}{ II. } & Associations including 2 taxons & & \\
\hline & S. aureus + M. lacunata & 5 & 10.64 \\
\hline & S. aureus $+N$. flavescens & 4 & 8.51 \\
\hline & S. haemolyticus + B. catarrhalis & 5 & 10.64 \\
\hline & S. epidermidis $+C$. albicans & 5 & 10.64 \\
\hline & S. pyogenes + Acinetobacter spp. & 2 & 4.26 \\
\hline & S. pyogenes $+K$. pneumoniae & 2 & 4.26 \\
\hline & E. coli + S. mutans & 2 & 4.26 \\
\hline & E. coli + S. mitis & 2 & 4.26 \\
\hline & S. aureus + S. sanguis & 1 & 2.13 \\
\hline & B. catarrhalis + E. cloacae & 1 & 2.13 \\
\hline \multirow{5}{*}{ III. } & Associations including 3 taxons & & \\
\hline & S. aureus + M. lacunata $+K$. pneumoniae & 1 & 2.13 \\
\hline & S. haemolyticus + C. albicans $+N$. flavescens & 1 & 2.13 \\
\hline & S. haemolyticus $+B$. catarrhalis $+S$. aureus & 1 & 2.13 \\
\hline & E. coli + C. albicans + Actinobacter spp. & 1 & 2.13 \\
\hline \multirow{5}{*}{ IV. } & Associations including 4 taxons & & \\
\hline & S. epidermidis $+B$. catarrhalis + E. cloacae $+S$. sanguis & 1 & 2.13 \\
\hline & S. aureus + C. albicans $+N$. flavescens + Actinobacter spp. & 1 & 2.13 \\
\hline & S. aureus $+S$. salivarius $+S$. sanguis $+K$. pneumoniae & 1 & 2.13 \\
\hline & S. haemolyticus + M. lacunata + S. salivarius + Actinobacter spp. & 1 & 2.13 \\
\hline
\end{tabular}


Table 4. Population level.

\begin{tabular}{|c|c|c|c|c|c|c|c|}
\hline \multirow[b]{2}{*}{ M.O. } & \multicolumn{3}{|c|}{ Patients $(n=47)$} & \multicolumn{3}{|c|}{ Apparently healthy individuals $(n=50)$} & \multirow[t]{2}{*}{$\mathrm{p}$} \\
\hline & $\begin{array}{c}\mathrm{PL}, \operatorname{lgCFU} / \mathrm{ml} \\
\mathrm{M} \pm \mathrm{m}\end{array}$ & CQD & $\mathrm{CS}$ & $\begin{array}{c}\text { PL, } \operatorname{lgCFU} / \mathrm{ml} \\
\mathrm{M} \pm \mathrm{m}\end{array}$ & CQD & CS & \\
\hline S. aureus & $6.11 \pm 0.34$ & 46.16 & 0.22 & 0 & - & - & - \\
\hline S. epidermidis & $5.18 \pm 0.27$ & 13.05 & 0.06 & $4.34 \pm 0.27$ & 14.61 & 0.063 & $<0.05$ \\
\hline S. haemolytics & $6.09 \pm 0.29$ & 20.44 & 0.1 & $3.78 \pm 0.19$ & 3.63 & 0.018 & $<0.01$ \\
\hline S. pyogenus spp. & $7.21 \pm 0.35$ & 24.2 & 0.11 & $3.27 \pm 0.17$ & 7.86 & 0.04 & $<0.01$ \\
\hline S. salivarius & $4.76 \pm 0.21$ & 4.28 & 0.02 & $7.67 \pm 0.41$ & 173.31 & 0.743 & $<0.01$ \\
\hline S. sanguis & $4.27 \pm 0.18$ & 5.37 & 0.03 & $5.11 \pm 0.31$ & 29.48 & 0.135 & $<0.05$ \\
\hline S. mutans & $4.31 \pm 0.16$ & 3.88 & 0.02 & $5.09 \pm 0.18$ & 19.58 & 0.086 & $<0.05$ \\
\hline S. mitry & $4.02 \pm 0.17$ & 3.62 & 0.02 & $5 . .7 \pm 0.22$ & 18.07 & 0.077 & $<0.05$ \\
\hline E. coli & $5.27 \pm 0.23$ & 15.48 & 0.07 & $3.30 \pm 0.17$ & 3.17 & 0.016 & $<0.01$ \\
\hline K. pneumoniae & $4.29 \pm 0.18$ & 7.2 & 0.03 & 3 & 1.44 & 0.007 & - \\
\hline E. cloacae & $4.78 \pm 0.27$ & 4.3 & 0.02 & 3 & 1.44 & 0.007 & - \\
\hline Actinobacter spp. & $5.21 \pm 0.33$ & 10.93 & 0.05 & $4.17 \pm 0.12$ & 10.02 & 0.05 & $<0.05$ \\
\hline B. catarralis & $5.93 \pm 0.41$ & 22.4 & 0.11 & 3 & 1.44 & 0.007 & - \\
\hline N. flavescens & $4.56 \pm 0.31$ & 13.39 & 0.06 & $3.62 \pm 0.11$ & 10.44 & 0.052 & $<0.05$ \\
\hline M. lacunata & $4.18 \pm 0.17$ & 12.28 & 0.06 & $3.47 \pm 0.16$ & 6.67 & 0.033 & $<0.05$ \\
\hline C. albicens & $4.97 \pm 0.29$ & 16.68 & 0.08 & 0 & - & - & - \\
\hline
\end{tabular}

\section{References}

[1] Pietiäinen M, Liljestrand JM, Kopra E et al. Mediators between oral dysbiosis and cardiovascular diseases. Eur J Oral Sci. 2018;126(1):26-36. DOI: https : //doi.org/10.1111/eos.12423

[PMid:30178551]

[2] Zhang M, Zheng Y, Li Y et al. Acidresistant genes of oral plaque microbiome from the functional metagenomics. J Oral Microbiol. 2018;10(1):1424455. DOI: https://doi.org/10. $1080 / 20002297.2018 .1424455$ [PMid:29503702 PMCid:PMC5795652]

[3] Zheng X, He J, Wang L et al. Ecological effect of arginine on oral microbiota. Scientific Reports. 2017;7:7206. doi: 10.1038 / s41598017-07042-w

[4] Vesty A, Biswas K, Taylor MW et al. Evaluating the impact of DNA extraction method on the representation of human oral bacterial and fungal communities. PLoS One. 2017;12(1):e0169877. DOI: https://doi.org/10. 1371 / journal.pone. 0169877

[PMid:28099455 PMCid:PMC5242530]

[5] Kilian M, Chapple IL, Hannig M et al. The oral microbiome - an update for oral healthcare professionals. Br Dent J. 2016;221(10):657666. DOI: https://doi.org/10.1038/ s j.bdj.2016.865 [PMid:27857087]

[6] Safarov AM. Mikrobnaya obsemenennost polosti rta pri nosheniyi syemnykh zubnykh protezov na osnove razlichnykh materialov. Sovremennaya stomatologiya. 2010;2:103105.

[7] Sokolova II, Skidan KV, Voropaeva LV et al. Mikroflora polosti rta, disbakterioz i puti yego korrektsiyi probiotikami. Eksperymenalna i klinichna medytsyna. 2010;2:64-69.

[8] Tsarev VN. Mikrobiologiya, virusologiya, immunologiya polosti rta: uchebnik. Tsarev VN, 
editor. Moscow: GEOTAR-Media; c2013. 576

p.

[9] Lewandowsky RA. Species composition and population level of the mouth microflora in people with complex maxillofacial pathology when using different types of prosthetic devices and its sensitivity to antiseptic preparations in Vitro. Clinical \& Experimental Pathology. 2014;13(1):69-74. [published in Ukrainian]

[10] Burdeniuk IP, Lewandowsky RA, Maksymiv $\mathrm{OO}$ et al. Aerobna ta fakultatyvno aerobna mikroflora rotovoii porozhnyny liudei zi skladnoiu shchelepno-lytsevoiu patolohiieiu, yaki korystuiutsia riznymy vydamy pokryvnykh, rezektsiinykh ta povnykh znimnykh proteziv ta vybirkova yii chutlyvist do dii deiakykh antyseptychnykh preparativ. Malanchuk VO, editor. Materialy VI Ukrainskoho Mizhnar. konhresu, prysviach. 100-richchiu z dnia narodzhennia prof. H.I. Semenchenko ta 95littiu kafedry khirurhichnoii stomatolohii ta shchelepno-lytsevoii khirurhii. Stomatolohiia. Implantolohiia. Osteointehratsiia; 2014; Kyiv. 299-305.

Received: 2019-07-03

Revised: 2019-08-19

Accepted: 2019-09-30 